\title{
The Ethics and Spirituality Initiative in Connection with the United Nations Sustainable Development Process
}

\author{
Herman F Greene*
}

\section{Abstract}

After twenty-five years sustainable development is not a reality. Policies and practices focus on the short-term and economists regard sustainable development as extraneous to their core responsibilities. Science, economics and selfinterest have not proven a sufficient ground for sustainable development. Ethics calling for moral reasoning and courageous action, spirit offering transcendence, vision and sustenance, and value asking what is development for are needed. United Nations negotiations have shaped, are shaping, and will continue to shape the meaning and practice of sustainable development. A global citizens' movement to build the political will for change is needed. To catalyze sustainable development ethics, religion and spirituality must operate out of a historical context and narrative of a "Great Transition." Ethics must enter at the ground level in determining how science, technology, and economics are to be conceived. Religion and spirit must begin with respect for the order of existence. A particular "Ethics and Spirituality Initiative for Sustainable Development" is building a coalition of religious, spiritual and secular values based-organizations to bring ethics and spirituality into the sustainable development process.

* President of Center for Ecozoic Societies, Chapel Hill, North Carolina, USA. Email: hfgreenenc@gmail.com 
This article is about an "Ethics and Spirituality Initiative for Sustainable Development," one that operates in relation to the United Nations sustainable development processes and requires transformative change and new narratives at personal, communal and policy levels. It discusses the current dilemma of sustainable development, the role of ethics, spirituality and value in resolving that dilemma, the meaning and history of sustainable development as expressed in the United Nations sustainable development processes, a way of understanding ethics and spirituality needed to catalyze sustainable development, and the status and prospect of this particular Ethics and Spirituality Initiative.

\section{Sustainable Development-The Dilemma}

"Sustainable development" is a familiar term, but one given to varying interpretations and seemingly adaptable to support any cause. For the Global North, it means a clean environment and a long-term trajectory toward clean energy and abatement of climate change. For the Global South, it means economic and social development and the shouldering of responsibility by the Global North for environmental debt and the global imbalances in wealth and technology. For some, sustainable development means radical change; and for others, it means greening the present economic system and business as usual.

It is a difficult term. Not only does it combine two sometimes divergent concepts, environmental sustainability and human development, it also is used in four ways: as (i) an idea, (ii) an action, (iii) a measurement, and (iv) a goal. Having been in widespread use for twenty-five years, it lacks novelty. For lack of novelty, difficulty of use and varying interpretations, it may be dismissed as being only marginally important. This, however, would be a mistake for it is the term on which the global dialogue on the future of humans and nature is being carried out. The dialogue is occurring at multiple levels, but first and foremost in the United Nations sustainable development negotiations. Neither the term, nor its contemporary relevance can be understood outside of the context of those negotiations. 
The lack of precision in the term sustainable development is concerning, but the seeming imprecision in the term results primarily from the way it counters the prevailing conception of development and requires transformation. Development, a term that only came into widespread use after World War II, has had a linear aspect to it and one primary goal - growth in per capita Gross Domestic Product ("GDP"). ${ }^{1}$ In development, problems are isolated and solved with little regard for their effect on the whole. Sustainable development, in contrast, requires holistic thinking. Issues are understood as involving interdependencies, and, in general, problems cannot be solved without multiple solutions by multiple actors at multiple levels. One might say sustainable development involves real world solutions, rather than abstract world-the world of humans and nature abstractly understood as one global, monetary economy - solutions.

Development has had astonishing achievements and has brought a better life for many. But its side effects are increasingly worrying. The current globalized mode of development has disrupted and is disrupting traditional ways of living and means of support. While it is lifting many people up, it is failing to meet the needs of billions of people and is making life worse for many; it is leading to increasing inequity and a seemingly intractable global divide between the rich and the poor, both within and between nations; and it is on a collision course with nature as providing a hospitable living space for humans and many other species.

Sustainable development was offered as a way of taking development forward without these harmful side effects. The question arises, then why has not more been accomplished? This

1 President Harry Truman in his inauguration speech before the United States Congress, on January 20, 1949, declared the largest part of the world, "underdeveloped." The world was defined as an economic arena and from then on the nations of the world could be assessed on a single scale based on GDP per capita. See discussion in Wolfgang Sachs, "The Archaeology of the Development Idea," Planetary Dialectics: Explorations in Environment and Development, Halifax, Nova Scotia: Fernwood Publishing, 1999, 3-24. 
was recently addressed in a report by the United Nations Secretary General's High Level Panel on Global Sustainability ("High Level Panel Report"):

A quarter of a century ago, the Brundtland report introduced the concept of sustainable development to the international community as a new paradigm for economic growth, social equality and environmental sustainability. The report argued that sustainable development could be achieved by an integrated policy framework embracing all three of those pillars. The Brundtland report was right then, and it remains right today. The problem is that, 25 years later, sustainable development remains a generally agreed concept, rather than a day-to-day, on-the-ground, practical reality. The Panel has asked itself why this is the case, and what can now be done to change that. (9)

The Panel has concluded that there are two possible answers. They are both correct, and they are interrelated. Sustainable development has undoubtedly suffered from a failure of political will. It is difficult to argue against the principle of sustainable development, but there are few incentives to put it into practice when our policies, politics and institutions disproportionately reward the short term. In other words, the policy dividend is long-term, often intergenerational, but the political challenge is often immediate. (10)

There is another answer to this question of why sustainable development has not been put into practice. It is an answer that we argue with real passion: the concept of sustainable development has not yet been incorporated into the mainstream national and international economic policy debate. Most economic decision makers still regard sustainable development as extraneous to their core responsibilities for macroeconomic management and other branches of economic policy. Yet integrating environmental 
and social issues into economic decisions is vital to success.

$(11)^{2}$

This High Level Panel Report was issued in preparation for the United Nation's third Earth summit, the United Nations Conference on Sustainable Development, held June 20-22, 2012, in Rio de Janeiro, Brazil. It was called "Rio+20," because the UN's first Earth summit had been held 20 years previously in Rio. Rio+20 should have been a time for major commitments on the part of governments to sustainable development, but it was not.

In the lead up to the conference, the question became more whether Rio +20 would be a source of regress rather than progress. On March 31, 2012, prominent civil society groups addressed an "Open Letter to the Secretary General for the United Nations Conference on Sustainable Development, the Secretary General and MemberStates of the United Nations, ${ }^{3}$ which observed with alarm:

We-the civil society organizations and social movements who have responded to the call of the United Nations General Assembly to participate in the Rio+20 process-feel that is our duty to call the attention of relevant authorities and citizens of the world to a situation that severely

2 United Nations Secretary-General's High-Level Panel on Global Sustainability, Resilient People, Resilient Planet: A Future Worth Choosing, New York: United Nations, 2012, ("High Level Panel Report"), 4-5 (emphasis added).

3 "Open Letter to the Secretary General for the United Nations Conference on Sustainable Development ("UNCSD"), the Secretary General and Member-States of the United Nations," March 31, 2012 (signed by Ibon International, Vitae Civilis, World Resources Institute, Stakeholder Forum, Council of Canadians, Consumers International, Sustain Labour, International Trade Union Confederation, CIVICUS, Women in Europe for a Common Future, Deutsche Umwelthilfe, European Environmental Bureau, Lake Constance Foundation, Fundación Global Nature España, and Global Nature Fund), https://www.civicus.org/en/what-we-do/crosscutting-projects/rio-20/ civicus-on-rio-20/782-rights-at-risk-at-theunited-nations (accessed June 10, 2012). 
threatens the rights of all people and undermines the relevance of the United Nations.

Remarkably, we are witnessing an attempt by certain countries to weaken, or "bracket" or outright eliminate nearly all references to human rights obligations and equity principles in the text, "The Future We Want", for the outcome of Rio+20.

This includes references to the right to food and proper nutrition, the right to safe and clean drinking water and sanitation, the right to development and others. The right to a clean and healthy environment, which is essential to the realization of fundamental human rights, remains weak in the text. Even principles previously agreed upon in Rio in 1992 are being bracketed-the Polluter Pays Principle, Precautionary Principle, Common But Differentiated Responsibility.

In the end Rio+20 reaffirmed prior commitments, but made few new ones. Intergovernmental negotiations were inconclusive right up to the week before the conference when the host government Brazil took over and proposed a final text for the outcome document, The Future We Want, ${ }^{4}$ on which the member nations were able to agree. In addition to reaffirmation of past commitments, the document, enhanced the institutional standing of the United Nations sustainable development processes and of the United Nations Environmental Program, and refined and prioritized the interconnected issues and the policies and practices of sustainable development.

Rio+20 were a missed opportunity. Now attention has turned to the three-year process of setting the UN's post-2015 development

4 The Future We Want, outcome document of the United Nations Conference on Sustainable Development, Rio de Janeiro, Brazil, June 20-22, 2012, available at http://www.un.org/ disabilities/ documents/rio20_outcome_document_complete.pdf(accessed November 12, 2012) ("Rio+20 Outcome Document"). 
agenda, as the Millennium Development Goals ("MDGs") 5 expire at the end of 2015. At that time, it is expected that the UN will adopt Sustainable Development Goals ("SDGs"). A crucial difference between the MDGs and the SDGs is that the MDGs set goals only for developing countries. The SDGs, in contrast, will apply to all countries and are expected to include goals related to sustainable consumption and production.

At present, there seems to be two unsatisfactory alternatives for the future: unsustainable development, and sustainable development that has not been practically demonstrated. The High Level Panel Report put it this way:

The current global development model is unsustainable. We can no longer assume that our collective actions will not trigger tipping points as environmental thresholds are breached, risking irreversible damage to both ecosystems and human communities. At the same time, such thresholds should not be used to impose arbitrary growth ceilings on developing countries seeking to lift their people out of poverty. Indeed, if we fail to resolve the sustainable development dilemma, we run the risk of condemning up to 3 billion members of our human family to a life of endemic poverty. Neither of these outcomes is acceptable, and we must find a new way forward. (8)

5 Millennium Development Goals (“MDGs”), http://www.undp.org/ content/undp/en/home/mdgoverview.html (accessed June 10, 2012). There are eight goals, 21 targets and a series of measurable indicators for each target, all to be achieved by 2015. The MDGs are eradicating extreme poverty and hunger, achieving universal primary education, promoting gender equality and empowering women, reducing child mortality rates, improving maternal health, combating HIV/AIDS, malaria, and other diseases, ensuring environmental sustainability, and developing a global partnership for development. 


\section{Resolving the Dilemma - Ethics, Spirituality and Value}

There are many reasons why the turn to sustainable development has not been made. It is difficult to change the current development model: People's lives depend on it; habits, cultures and institutions are set for it; and its promise of material abundance is attractive. Even if it is a high stakes gamble that it cannot succeed has not been proven - there may be technological breakthroughs that will make it sustainable. Further, on the negative side, business as usual is demanding and people are constrained by it. Change seems a luxury when one can barely get by and is in debt - this is true for nations as well as people. Competition requires one to run hard just to stay in place - this is true for nations as well as people. And if one enjoys the private benefits of wealth, especially new wealth, why change?

All the arguments are against sustainable development until one looks at the necessity for it. Then it becomes a moral imperative. In the short-term, however, it is the more difficult and expensive path. This is illustrated by the effect of Hurricane Sandy and its aftermath. Given changing weather conditions, but also long inattention, the energy, transportation and flood water protection infrastructures of Manhattan have been proven inadequate. Now Mayor Bloomberg of New York City and Governor Cuomo of New York are calling for billions of dollars of funding at state and federal levels to rebuild them at a time when both the state and federal budgets are stressed and deeply in debt. The situation in New York City (and along the north eastern coast of the United States generally) garnering public attention has a certain immediacy to it, though the public attention may decline as memories of the storm fade.

The other side of sustainable development is attention to the needs of the poor. The havoc in New York City after Hurricane Sandy is the daily reality for many (human and non-human) in the world. They too call out for help to a world that is stressed and deeply in debt. As was shown in Rio+20 and in the recent climate change conferences, government commitments are becoming, with wider knowledge, not easier but more difficult to come by. 
In the history of the UN negotiations on sustainable development, there is much clarity on what is required. The key problem is a failure of will, failure to undertake transformative/systemic change as opposed to incremental change. For the last twenty-five years arguments for sustainable development have largely been based on science, economics and self-interest. Now leaders, even at the highest levels, are recognizing that ethics, spirituality and value must be brought into the mix.

For example the High Level Panel Report states:

The Panel welcomes discourse on the ethical dimensions of sustainable development at the United Nations Conference on Sustainable Development ("Rio+20") in 2012 among all stakeholders, based on relevant experience and instruments, including the Earth Charter, to inform Governments in their efforts to shift to sustainable development.(14) ${ }^{6}$

The United Nations Secretary-General's UN System Task Team Report, Realizing the Future We Want for All, which was released just after Rio+20 and set the stage for the Post-2015 process, stated:

Business as usual thus cannot be an option and transformative change is needed. As the challenges are highly interdependent, a new, more holistic approach is needed to address them. Accordingly, this first report prepared by the UN System-wide Task Team on the Post-2015 UN Development Agenda recommends: "A vision for the future that rests on the core values of human rights, equality and sustainability." 7

\section{And later it states:}

This report presents a vision for the post-2015 UN development agenda as one that seeks to achieve inclusive, people-centred, sustainable global development: 'the future

High Level Panel Report, 12 (emphasis added).

7 UN System Task Team on the UN Post-2015 Development Agenda, Realizing the Future We Want for All: Report to the Secretary General (July 2, 2012) (emphasis added) ("Task Team Report"). 
we want for all.'[T]his will require transformative change in existing production and consumption processes, management of natural resources and mechanisms of governance This, in turn, calls for a broad approach to development based on social justice, structural transformation, economic diversification and growth. (51)

The vision described here is holistic and global. It recognizes both the need for policy coherence and the diversity of contexts and challenges within and among countries. While no specific development path will suit all situations, two elements should be seen as common: first, core values, principles and standards derived from internationally-adopted normative frameworks should be explicitly integrated into the global development agenda and corresponding national strategies; and, second, the shorter-term pursuit of verifiable progress should support and affirm those principles. Founded on core values, transformative change will be fuelled by policy innovation and experimentation, as well as mutual and participatory learning. $(52)^{8}$

Modernity promises a value-free world of endless growth. The universe has no meaning or purpose and no divinity. The economy functions best when all pursue their own interest. Politics is power and science is the technology for controlling the conditions of existence. Modernity avoids hard choices, but now there are hard choices to be made. Ethics is needed for moral reasoning and courageous action. Spirit is needed for transcendence, inspiration and sustenance. Value is needed to re-orient what development is for - that in the end it is not about having more, but about being more.

Perhaps humankind is entering the post-secular age, as Habermas has called it, ${ }^{9}$ not merely because religion has endured, but rather

Task Team Report, 21-22.

See, e.g., Eduardo Mendieta, Matthias Fritsch, trans., "A Postsecular World Society: An Interview with Jürgen Habermas," The Immanent Frame, available at http://blogs.ssrc.org/tif/wp-content/ uploads / 
because ethics, spirituality and value are needed. Welcoming them back is not done without trepidation for this is a journey from the rationality, secularism and empiricism of modernity to the transrational soul of self, soul of community and culture, and soul of the universe. As history has shown there is a shadow side of this, so discernment is required. ${ }^{10}$ As history has also shown transformative change doesn't occur without them.

\section{The Original Definition of Sustainable Development: The Brundtland Report}

As stated earlier, the term sustainable development cannot be understood outside the context in which it arose and continues to be developed, the UN sustainable development processes.

The original definition of sustainable development comes from Paragraph 27 of the 1987 Report of the World Commission on Environment and Development: Our Common Future ("Brundtland Report," ${ }^{11}$ which provided as follows: "Humanity has the ability to make development sustainable to ensure that it meets the needs of the present without compromising the ability of future generations to meet their own needs." (27)

From this came the commonly stated definition "Sustainable development is development that meets the needs of the present

2010/02/ A-Postsecular-World-Society-TIF.pdf (accessed November 15, 2012).

10 For a thoughtful reflection on this, see "Habermas' Notion of a PostSecular Society: A Perspective from International Relations," EUI Working Papers, MWP 2008/25; available at http://cadmus.eui.eu/ bitstream/handle/1814/9011/MWP_2008_25.pdf?sequence=1

(accessed November 15, 2012).

11 World Commission on Environment and Development (Gro Harlem Brundtland, Chairman), Report of the World Commission on Environment and Development: Our Common Future, transmitted to the General Assembly as an Annex to document A/42/427 - Development and International Co-operation: Environment (August 4, 1987) ("Brundtland Report"). 
without compromising the ability of future generations to meet their own needs."

Gro. Harlem Brundtland, in the "Chairman's Foreword" to the report candidly acknowledge the tensions that were involved in considerations of sustainable development. These were, among others, tensions between rich nations and poor nations, between coordinated or global governance and national sovereignty, between economic development and environment, and between economic growth and equity. Given the initial charge of the Commission, to study economic and social development in relation to environment, the fundamental tension involved development and environment. Brundtland described the approach taken by the Commission in resolving this conflict as follows:

When the terms of reference of our Commission were originally being discussed in 1982, there were those who wanted its considerations to be limited to "environmental issues" only. This would have been a grave mistake. The environment does not exist as a sphere separate from human actions, ambitions, and needs and attempts to defend it in isolation from human concerns have given the very word "environment" a connotation of naivety in some political circles. The word "development" has also been narrowed by some into a very limited focus, along the lines of "what poor nations should do to become richer", and thus again is automatically dismissed by many in the international arena as being a concern of specialists, of those involved in questions of "development assistance".

But the "environment" is where we all live; and "development" is what we all do in attempting to improve our lot within that abode. The two are inseparable. Further, development issues must be seen as crucial by the political leaders who feel that their countries have reached a plateau towards which other nations must strive. Many of the development paths of the industrialized nations are clearly unsustainable. And the development decisions of these countries, because of their great economic and political 
power, will have a profound effect upon the ability of all peoples to sustain human progress for generations to come.

Many critical survival issues are related to uneven development, poverty, and population growth. They all place unprecedented pressures on the planet's lands, waters, forests, and other natural resources, not least in the developing countries. The downward spiral of poverty and environmental degradation is a waste of opportunities and of resources. In particular, it is a waste of human resources. These links between poverty, inequality, and environmental degradation formed a major theme in our analysis and recommendations. What is needed now is a new era of economic growth - growth that is forceful and at the same time socially and environmentally sustainable. ${ }^{12}$

Thus, from the beginning, sustainable development has been a compromise between those who want to privilege environment and those who want to privilege economic development, the compromise being that the concern for economic development would be primary and social and environmental concerns would condition development.

\section{Ideas Strongly Associated with Sustainable Development}

In addition, to the basic definition of sustainable development in the Brundtland Report, two other sets of ideas have become strongly associated with the term sustainable development and must be taken into account when using or debating the term. The first is the set of principles adopted at the 1992 Earth Summit in the Rio Declaration of Environment and Development ("Rio Declaration"). ${ }^{13}$ These principles include, among others, "the right

“Chairman's Foreword," Brundtland Report.

The Rio Declaration on Environment and Development, http://www.unep.org/Documents.

Multilingual/Default.asp?documentid=78\&articleid=1163 (accessed June 10, 2012) (“Rio Declaration"). 
to development (the right to full human development of all, and, also, the right of nations to exploit their own resources with due regard for their freedom and identity and removal of obstacles to development), ${ }^{14}$ environmental protection, eradication of poverty, protection of future generations, common but differentiated responsibilities, ${ }^{15}$ sustainable production and consumption by all states, capacity building and technology transfer, transparency and access to information, free trade, the precautionary approach, and full participation of women and indigenous people."

The second is the idea that there are three pillars of sustainable development, economic, social and environmental. ${ }^{16}$

See, The Declaration on the Right to Development, A/Res/41/128, 1986, which begins: Article 1: 1 . The right to development is an inalienable human right by virtue of which every human person and all peoples are entitled to participate in, contribute to, and enjoy economic, social, cultural and political development, in which all human rights and fundamental freedoms can be fully realized. 2 . The human right to development also implies the full realization of the right of peoples to self-determination, which includes, subject to the relevant provisions of both International Covenants on Human Rights, the exercise of their inalienable right to full sovereignty over all their natural wealth and resources.

15 Principle 15 of the Rio Declaration states: "In view of the different contributions to global environmental degradation, States have common but differentiated responsibilities. The developed countries acknowledge the responsibility that they bear in the international pursuit of sustainable development in view of the pressures their societies place on the global environment and of the technologies and financial resources they command."

16 These three pillars are well discussed in Robert W. Kates, Thomas M. Parris, and Anthony A. Leiserowitz, "What is Sustainable Development?" Environment: Science and Policy for Sustainable Development, 47, No. 3 (April 2005): 12, http://www.rpdmohesr.com/uploads/custompages/

WHAT\%20IS\%20SUSTAINABLE\%20DEVELOPMENT.pdf (accessed June 10, 2012). The 2002 World Summit on Sustainable Development marked a further expansion of the standard definition with the widely used three pillars of sustainable development: economic, 


\section{Strong Sustainability}

The term sustainable development was originally meant to deal with economic development in the context of the environment and has come to cover all aspects of economic and social development and to address social imbalances that have occurred over centuries. Some have felt that, in doing so, not enough emphasis has been given to environment - not just for nature itself, but because nature, as the wider community of life and life processes, is fundamental to the health of the human community and instructive on the true meaning of development. Following this line of thought, a significant number of civil society groups have argued for a strong definition of sustainability. Here are two ways they have expressed what strong sustainability means.

A strong definition of sustainable development recognizes the three standard pillars - social, environmental and economic - but organizes them in a particular way. Environment is not merely the resource base for human consumption, not just one of the three factors to be considered. Rather, it incorporates the greater community of life including human beings and the life-support systems on which we all depend. This shift to a broader life-centred

social, and environmental. The Johannesburg Declaration created "a collective responsibility to advance and strengthen the interdependent and mutually reinforcing pillars of sustainable development-economic development, social development and environmental protection-at local, national, regional and global levels." In so doing, the World Summit addressed a running concern over the limits of the framework of environment and development, wherein development was widely viewed solely as economic development. For many under the common tent of sustainable development, such a narrow definition obscured their concerns for human development, equity, and social justice. Thus while the three pillars were rapidly adopted, there was no universal agreement as to their details. 
perspective marks one key difference between "weak" and "strong" sustainability. ${ }^{17}$

"Sustainable," by definition, means not only indefinitely prolonged, but nourishing, as the Earth is nourishing to life, and as a healthy natural environment is nourishing for the self-actualizing of persons and communities. The word "development" means the evolution, unfolding, growth, and fulfilment of any and all aspects of life. Thus "sustainable development," in the broadest sense, may be defined as the kind of human activity that nourishes and perpetuates the historical fulfilment of the whole community of life on Earth. ${ }^{18}$

Another concept advanced in support of a strong definition of sustainability is that of a "wedding cake" in which the environment is at the base, society is embedded in the environment and economics is embedded in society. Such a wedding cake with economics being the smallest layer would arguably be a reversal of the present situation in which economics is fundamental, society is an outgrowth of the economy, and the environment is an outgrowth of society.

\section{Human-Centred Development}

While some have felt sustainable development should give more weight to nature, others have emphasized the human side of development, though not development in the conventional sense. In the 1990s while the Global North emphasized environment, the Global South argued that even though environment is important, human needs come first. The Rio Declaration thus begins: Principle 1: "Human beings are at the centre of concerns for sustainable

17 Earth Charter International, "Recommendations for the Zero Draft of the UNCSD (Rio+20) Outcome Document, Major Groups Compilation Document," 286, http://www.uncsd2012.org/rio20/ comp_mgs.html (accessed February 7, 2012).

18 Stephen Rockefeller and John Elder, Spirit and Nature: Why the Environment is a Religious Issue--An Interfaith Dialogue (Boston, MA: Beacon Press, 1992), 8. 
development. They are entitled to a healthy and productive life in harmony with nature."19

Later as businesses adopted the term, globalization and neoliberal economics triumphed in the post-Cold War period, and conservative governments came to power in key developed countries, focus on the economy became paramount.

And more recently as developed countries have faced financial crisis and have pulled back on global environment and development assistance, and as less developed countries, at both the governmental and popular levels, have become more aware of inequity in the global economy and of their own identities and aspirations and how they are affected by globalization, there has been a call for human rights-based sustainable development, ${ }^{20}$ including rights to "such basic requirements as clean water, sanitation, adequate shelter, energy, health care, [and] food security." 21 (A member of the United Nations recently said to the author that she was trained to never use the term "sustainability" alone, but always to use the complete term "sustainable development.")

\section{Inclusiveness}

Thus, the term "sustainable development" is vague. It means different things to different people and is used to advance diverse interests. What it lacks in clarity, however, it makes up for in inclusiveness - it brings everyone to the table even those who

19 Rio Declaration, Principle 1.

20 See, for example, Economic Commission for Latin America and the Caribbean Subregional Headquarters for the Caribbean, Sustainable Development From a Human Rights Perspective and the Challenges It Represents for the Caribbean SIDS, LC/CAR/L.123 (June 29, 2007), http://www.eclac.org/publicaciones/xml/9/29209/1.123.pdf (accessed November 15, 2012).

21 Johannesburg Declaration on Sustainable Development, Doc. A/CONF.199/20 (2002). 
normally would not be in dialogue with each other. ${ }^{22}$ It has been clear from the beginning that sustainable development is not a solution to alleviate a particular problem, but a term that identifies a transformation that needs to occur in all sectors of society and in all nations and locations. Everyone is involved in this transformation and no other concept has been able to bring all the needed actors and issues into the dialogue.

Sustainable development is destiny. Events brought the term into being and events require its continued usage. Now, twenty-five years on, it is established in the global lexicon and is used and understood in all nations. If, as many believe, transformational global change must occur by 2050, there is not time to develop another language and framework for addressing the present Earth and human civilizational crises. It is the term based on which the future of the world will be debated and determined over the crucial next forty years.

22 This thought was expressed in Wolfgang Sachs, ed., The Jo'Burg Memo: Fairness in a Fragile World, 2d ed. (Berlin, Germany: Heinrich Böll Foundation, 2002), http://www.worldsummit2002.org/ publications/memo_en_with.pdf (accessed June 10, 2012), 2, as follows: The very notion of "sustainable development", around which the [1992] Rio Conference revolved, has evolved into a highly successful compromise. While developers and environmentalists had opposed each other for decades, the concept forced them onto one common terrain. Shell [oil] together with Greenpeace, the World Bank as well as the anti-dam movement invoke "sustainable development"; few outrightly deny the concept. On the contrary, the idea works like an all-purpose cement, gluing everybody together, friends and foes alike. In the wake of this semantic innovation both the development enthusiasts and the nature lovers had to revise their positions, creating a common ground that facilitated a productive exchange between established institutions and their vocal opponents. Certainly, the price paid for this consensus was clarity. Dozens of definitions are used by experts and politicians, with the result that conflicting interests and visions disguised as the same idea. But precisely this power of inclusion proved to be the strong point of "sustainable development". Rarely had a conference [Rio 1992]] made such an impact on the political landscape simply through the means of language. 


\section{History of the UN Sustainable Development Process}

Here are some key events in the history of the UN sustainable development process. These events do not stand in isolation. Each one represents a coming together of the global community and global currents at a moment in time to give meaning and effect (or to temper or block the effect) of the concept of sustainable development.

1972: United Nations Conference on the Human Environment held in Stockholm, Sweden. This was the UN's first international conference on the environment. Rio+20 could as well have been called Stockholm +40 . The conference adopted the "Stockholm Declaration," which began: Man has the fundamental right to freedom, equality and adequate conditions of life, in an environment of a quality that permits a life of dignity and well-being, and he bears a solemn responsibility to protect and improve the environment for present and future generations. ${ }^{23}$ The UN Environmental Program came into being as a result of the conference.

1982: The UN General Assembly adopts the World Charter for Nature, which takes a bio centric view and remains the UN's strongest statement on the integrity of nature. ${ }^{24}$

1987: The Brundtland Report is published. This landmark report was an attempt to reconcile the objectives of economic development and the environment. It also focused on the

United Nations Conference on the Human Environment, Declaration of the United Nations Conference on the Human Environment (June 16, 1972), Principle 1, http:/ / www.unep.org/Documents. Multilingual/ Default.asp?documentid=97\&articleid=1503 (accessed June 10, 2012).

United Nations General Assembly, World Charter for Nature (1982), http://www.un.org/ documents/ga/res/37/a37r007.htm (accessed June 10, 2012). The first two principles are: 1 . Nature shall be respected and its essential processes shall not be impaired. 2. The genetic viability on the earth shall not be compromised; the population levels of all life forms, wild and domesticated, must be at least sufficient for their survival, and to this end necessary habitats shall be safeguarded. 
need to eradicate poverty as a fundamental requirement of environmentally sustainable development. The Brundtland commission was established by a resolution of the UN General Assembly in 1983 and disbanded after the report was published.

1992: United Nations Conference on Environment and Development is held in Rio de Janeiro, Brazil. The 1992 Rio conference set forth a comprehensive agenda (over 300 pages long) for sustainable development called Agenda 21: Programme of Action for Sustainable Development ("Agenda $\left.21^{\prime \prime}\right) .{ }^{25}$ The conference also adopted the Rio Declaration and Statement of Forest Principles.26 Further, the UN Framework Convention on Climate Change and the Convention on Biological Diversity were opened for signature during the Earth Summit, and Agenda 21 recommended the establishment of the Commission on Sustainable Development as a functional commission of the UN Economic and Social Council to ensure effective follow-up of Rio. Following the conference the Commission on Sustainable Development was established.

2000: United Nations Millennium Summit is held at UN headquarters in New York City. Its purpose was to discuss the role of the United Nations at the turn of the 21st century. At the summit world leaders ratified the "Millennium Declaration" and three days later this was adopted by the

United Nations Conference on Environment and Development, Agenda 21: Earth Summit-The United Nations Programme of Action from Rio (New York: United Nations Department of Public Information, 1992).

Non-Legally Binding Authoritative Statement of Principles for a Global Consensus on the Management, Conservation and Sustainable Development of all Types of Forests, A/CONF.151/26 (Vol. III), 1992, http:// www.un.org/documents/ga/conf151/aconf15126-3annex3.htm (accessed November 15, 2012). 
UN General Assembly. ${ }^{27}$ Following the Millennium Summit, the Millennium Development Goals, ${ }^{28}$ which were based on the Millennium Declaration, were adopted.

2000: The Earth Charter29 ("Earth Charter") is adopted at a meeting of the Earth Charter Commission held at UNESCO headquarters in Paris in March 2000. The Earth Charter is officially launched at the Palace of Peace in The Hague in June 2000. While not an official UN document, it is regarded as an important statement of values by $\mathrm{UNESCO}^{30}$ and is often regarded as a summary of the values of sustainable development and as the sentinel statement of strong sustainability.

2002: World Summit on Sustainable Development is held in Johannesburg, South Africa. The summit adopted the Johannesburg Plan of Implementation ${ }^{31}$ and the Johannesburg

UN General Assembly, United Nations Millennium Declaration, A/RES/55/2, 2000, http://www.un.org/ millennium/declaration/ ares552e.pdf (accessed June 10, 2012).

MDGs, see Note 5 above.

29 Earth Charter Commission, The Earth Charter (2000), http://www.earthcharterinaction.org/ content/pages/Read-theCharter.html (accessed June 10, 2012).

30 A UNESCO website on the Earth Charter states: "The Earth Charter serves as a base of ethical principles inspiring the Decade of Education for Sustainable Development. It fleshes out fundamental principles to build a just, sustainable and peaceful global society. It promotes an integrated approach to global issues." http://www.unesco.org/ en/esd/programme/ethical-principles / the-earth-charter/ (accessed June 10, 2012).

World Summit on Sustainable Development, Johannesburg Plan of Implementation, A/CONF.199/20 (September 4, 2002), http://www.un.org/esa/sustdev/ documents/ WSSD_POI_PD/ English/ WSSD_PlanImpl.pdf (accessed November 17, 2012). 
Declaration on Human Development. 32 This summit was considered by many to be a setback, at least on environmental issues. The plan adopted at the summit was criticized, for example, by the Heinrich Böll Foundation "for not having real new commitments, targets and funding for implementation provided. [Critics also argued that the summit] put poverty eradication in the forefront while advancing economic growth as the main strategy for poverty eradication. This would result in the usual recipes for economic growth." 33

2005: World Summit High-level Plenary Meeting of the 60th Session of the General Assembly is held at the UN headquarters in New York City. This was a follow-on meeting to the Millennium Summit. The appointment of John Bolton as US Ambassador shortly before the summit changed the proceedings. Bolton argued against the MDGs, for UN reform, and against reproductive rights and family planning and women's rights generally as expressed in previous UN documents. Sustainable development was not a major focus of this conference, except in the sense of poverty alleviation and financing for development. The primary concerns were security related.

2011: 64 $4^{\text {th }}$ Annual United Nations Conference for NonGovernmental Organizations associated with the Department of Public Information, on the theme "Sustainable Societies; Responsive Citizens" is held in Bonn, Germany. ${ }^{34}$ The conference adopted the Bonn Declaration on

32 World Summit on Sustainable Development, Johannesburg Declaration on Sustainable Development, A/CONF.199/20, (September 4, 2002), http://www.un-documents.net/jburgdec.htm.

33 "What Are the Outcomes of the World Summit?" (2002), http:/ / www.worldsummit2002.org/ (accessed June 10, 2012).

The United Nations Department of Public Information coordinates relations with over 3,000 NGOs that have consultative status with the UN. Its services to NGOs include the Annual UN DPI/NGO Conference. The 2011 conference was concerned with the 10-year 
Sustainable Societies; Responsive Citizens, ${ }^{35}$ a document that was addressed to the 10-year anniversary of the Year of the Volunteer and preparation for Rio+20.36 This Declaration called for the broadest possible outcomes at Rio+20, outcomes that were not e realized. It is a visionary document and of continuing importance.

2012: UN Conference on Sustainable Development is held in Rio de Janeiro, Brazil, June 20-22, 2012. Rio+20, standing in the line of the 1992 Earth Summit in Rio and the 2002 Earth Summit in Johannesburg, was the UN's third Earth Summit. The outcome document from the conference was titled The Future We Want. 37 Representatives of 191 UN member states participated in the preparation for Rio+20 or attended the conference itself, 79 Heads of State or Government addressed the proceedings, and 44,000 badges were issued for official meetings, with most of those going to members of civil society. Over 500 side events were held by nongovernmental organizations at Rio+20. While declared to be the most participatory conference in history by the President of Rio+20, Dilma Rousseff of Brazil, it was

anniversary of the International Year of the Volunteer and preparation for Rio+20.

35 Annex to the letter dated 7 October 2011 from the Permanent Representative of Germany to the United Nations addressed to the President of the General Assembly, Declaration Adopted at the SixtyFourth Annual Conference of the Department of Public Information for Non-Governmental Organizations Bonn, Germany, 3-5 September 2011, Sustainable Societies; Responsive Citizens, A/66/750, http:/ / www.lwv.org/files/UN\%20Bonn\%20Declaration.pdf (accessed June 10, 2012).

36 According to the Rio+20 website, "The Rio+20 text [in this declaration] is the first attempt to put together some ideas on Sustainable Development Goals which were put on the table by Columbia in June [2011]." "Outcomes from Bonn UN DPI Conference," http://www.uncsd2012.org/ rio20/ index.php?page $=$ view \&nr=320\&type $=230 \&$ menu $=38$ (accessed June 12, 2012).

Rio+ 20 Outcome Document. 
nonetheless a disappointment for most due to few new commitments..$^{38}$ It is wrong, however, to see this gathering of people concerned about sustainable development as a failure. In addition to the official summit, an estimated 3,000 informal events were held in parallel in Rio, including a large People's Summit. And nongovernmental organizations, claiming outcomes not possible in the official meeting, issued fourteen People's Sustainability Treaties. ${ }^{39}$ Few left Rio+20 with a feeling that what was needed had been accomplished. Political conditions, such as the US Presidential campaign, and financial conditions, such as the Euro crisis, among other things, affected what could be accomplished. A positive outcome of Rio+20 for many civil society attendees was a resolve to build the political will for change-especially in regards to shaping the post-2015 UN development agenda.

2012: UN System Task Team on the UN Post-2015 Development Agenda publishes Realizing the Future We Want for All: Report to the Secretary General. 40 The MDGs expire in 2015. The work on the MDGs and the work on sustainable development have proceeded on separate tracks, although efforts are being made, including at Rio+20, to integrate sustainable development into all United Nations activities. This report

38 For a thorough report on the conference and its outcome, See "Summary of the United Nations Conference on Sustainable Development: 13-22 June 2012," Earth News Bulletin 27, No. 51 (June 25, 2012), http://www.iisd.ca/download/pdf/enb2751e.pdf (accessed November 15, 2012). The commitments made at Rio+20 primarily concerned institutional structures for sustainable Development. The Outcome Document called for the UN General Assembly to further integrate sustainable development in its work, for the strengthening of ECOSOC, and for the Commission for Sustainable Development to be replaced by an intergovernmental high level political forum.

39 Copies of the treaties are available at www.sustainabilitytreaties.org (accessed November 15, 2012).

Task Team Report. 
signaled the beginning of a three-year process to shape the post-2015 development agenda of the UN. This process is being co-chaired by the UN Department of Social Affairs and the UN Development Program. The report lays out an open and transparent plan for shaping the new goals, which may be called the sustainable development goals. The process involves consultations in more than fifty states and many other steps leading up to a potential "special event" in the 68 $8^{\text {th }}$ General Assembly, which begins in fall 2013. The Rio+20 Outcome document calls for a parallel process involving an Open Working Group of thirty representatives to propose sustainable development goals by 2013 .

\section{Importance of the United Nations}

The UN is the only truly international institution in the world. The UN lacks coercive power, but it is where the world meets to discuss the common concerns and aspirations of the world's people. Sustainable development cannot occur as a local or even national, bottom-up effort only. The world is too interconnected and interactive. As distant and ineffectual as the negotiations in the UN may seem, they are the working out of a global consensus on the development path of the future. The UN is the meeting place of civil society, governments, and business. Some, especially in the United States, fear that the UN is the coming of global government. This fear is misplaced. If sustainable development is to occur, the $\mathrm{UN}$ is the coming of global governance. For this to occur, however, will not be determined in the UN. It will depend on efforts in all sectors of society and the building of a global citizens' movement. The needed global citizens' movement is not a global movement of citizens; it is a movement of people who come to understand themselves as global citizens. This is required for humanity is in the planetary phase of development. ${ }^{41}$

41 The idea that we are in the "planetary phase" of civilization is taken from Paul Raskin, et. al., "The Planetary Phase," Great Transition: The Promise and Lure of the Times Ahead, Boston, MA: Stockholm Environment Group, 2002, 5-11. 


\section{An Understanding of Ethics and Spirituality for Sustainable Development}

Sustainable development is not simply a desirable choice, among others, it is a necessity, and therefore a moral imperative. For sustainable development to occur, ethics is needed to promote moral reasoning and courageous action. Spirit is needed to transform and inspire and to support people in making difficult choices, living in hard times, letting go of the past and embracing an uncertain future. The term "sustainable development," while essential, does not communicate a sense of urgency. There needs to be an accompanying narrative and understanding that compels action. We now live in a full world with little unused land, resources, or waste sinks to exploit. Given the technological capacity of humans, human impacts on natural systems and species, and the growing size of unmet human needs, the changes required are vast and are of an order-of-magnitude of civilization change. Furthermore, given the forecasts of climate change, population growth, diminishing food supplies, acidification of oceans, species loss, and desertification, among other like issues, this change must occur by 2050 in order to avoid catastrophic consequences 42 - change of this magnitude has never occurred before in such a short period of time.

42 In preparation for Rio+20, four key reports were issued on the state of the planet: WWF, Living Planet Report 2012 - Special Edition - On the Road to Rio+20, Gland, Switzerland: WWF, 2012, which stated on page 1, "We are living as if we have an extra planet at our disposal. We are using 50 per cent more resources than the Earth can provide, and unless we change course that number will grow very fast - by 2030, even two planets will not be enough"; UNEP, GEO-5: Environment For The Future We Want, Nairobi, Kenya: UNEP, 2012, which reported on page 4 ," The scale, spread and rate of change of global [environmental change] drivers are without precedent. Burgeoning populations and growing economies are pushing environmental systems to destabilizing limits"; Lidia Britto and Mark Stafford Smith, "State of the Planet Declaration," reporting on key messages emerging from the Planet Under Pressure Conference held in London, UK, March 26-19, 2012, a gathering of 3000 global change scientists and other experts, which stated " Research now 
The ethics and spirituality that will catalyze sustainable development must operate out of this historical context. It must also be grounded in a narrative ${ }^{43}$ of a "Great Transition," 44 a "Great Turning," 45 the "Great Work of moving from a terminal Cenozoic to an emerging Ecozoic Era," 46 the transition from "industrial civilization to ecological civilization," 47 the transition from an "economic age to a cultural age," 48 or other like narrative that communicates humankind is at a major transition point in history,

demonstrates that the continued functioning of the Earth system as it has supported the well-being of human civilization in recent centuries is at risk"; Kate Raworth, A Safe and Just Place for Humanity: Can We Live Within the Doughnut?, Oxford, UK: Oxfam GB, 2012, which focused on poverty and a social floor, and reported on populations living below that floor, and a ceiling imposed by planetary boundaries, and reported ways that humans cumulative exceed or pressure these boundaries.

43 For the importance of narratives to ecological ethics, see Arran Gare, "Narratives and the Ethics and Politics of Environmentalism: The Transformative Power of Stories," Theory and Science 2, no, 1 (spring 2001); http://theoryandscience.icaap.org/volume2issue1.php (accessed November 16, 2012).

44 Great Transition Initiative, http://gtinitiative.org/ (accessed November 16, 2012).

45 Joanna Macy, "The Great Turning," http://www.ecoliteracy.org /essays/great-turning (accessed November 16, 2012); and David Korten, "The Great Turning: An Epic Passage," http://www.davidkorten.org /great-turning (accessed November 16, 2012).

46 Thomas Berry, The Great Work: Our Way into the Future (New York, Bell Tower, 1999).

47 Department of Hominology, Peking University, "Invitation for International Symposium on Ecological Civilization," December 1, 2008.

48 D. Paul Schafer, Revolution or Renaissance: Making the Transition from an Economic Age to a Cultural Age, Ottawa, Canada: Ottawa University Press, 2008. 
one that calls for transformational change and not just incremental improvement. Further this narrative must speak to the chaos and compression of transition, to the need for the transition to occur globally in a short timeframe that is unprecedented, and of the uncertainty of results along with the hope for a viable Earth community and fuller humanity.

It is important to distinguish the kind of ethics and spirituality that are needed to catalyze sustainable development. With regard to ethics, as Arran Gare has written, it is not:

a kind of add-on, where after everything else has been worked out people then consider the supposed ethical obligations of actors or the ethical implications of actions (as such it's like using a bicycle brake to stop a 747); as with much of contemporary philosophy, an effort that denies to ethics and political philosophy any relevance to efforts to advance our understanding of the cosmos and our place within it; an academic sub-discipline of ethics, which is a sub-discipline of philosophy, and as such, is dissociated from political and social philosophy, which in turn have largely ignored the rise of economics and the new discipline of public policy studies which have displaced them when it comes to influencing how politics actually works; or environmental management, which is succeeding ecological ethics and emerging as a new discipline offering training for a career in managing the environment, excluding others from the field and reinforcing the division of roles, allowing the general public to leave environmental issues to the experts. ${ }^{49}$

Rather ethics must be understood as something that is "inseparable from political philosophy, economics, science, religion, culture and civilization and studies of the proclivities of individuals and societies for good and bad, nobility and evil. Rather than standing

49 Arran Gare, "Process Philosophy and Environmental Ethics," Applied Process Thought: Initial Explorations, ed. Mark Dibben and Thomas Kelley, Frankfort, Germany: Ontos Verlag, 2008, 365-66. 
above science, technology and economics as a set of injunctions, ethics enters at the ground level determining how science, technology and the economy are to be conceived." 50

Ethics binds us to equity, community and shared responsibility. Equity has two dimensions, absolute and relative: Absolute equity involves the demand to meet basic human needs, eradicate poverty, and preserve life support systems. Relative equity concerns fairness. ${ }^{51}$ Of the two, absolute equity is primary.

With regard to religion and spirit, the Triglav Circle's submission to the Rio+20 compilation document provides key guidance. The submission offers this quote by Vaclav Havel:

Is not the essence of the environmental crisis related to the loss of respect for the order of existence in which humankind is not the creator, but a mere component of its mysterious meaning or spirit? [...]. Is not the crisis the logical consequence of the perception of the world as a complex of phenomena controlled by certain scientifically established laws and [ignoring] questions on the meaning of existence and [the relevance] of metaphysics?

And then the submission continues

Absent in the present discourse is meaningful appreciation of the limits to humankind's capacity to learn the larger truths of existence through scientific rationality. Empiricism cannot frame all the questions and provide all the answers. For Havel, only an awakening of the human spirit can help society address the fundamental causes of the current environmental crisis. A prerequisite for any effective

50 Arran Gare, email message to author, December 10, 2011

51 Wolfgang Sachs, "Preface to the New Edition," The Development Dictionary, 2d edition, ed. Wolfgang Sachs, New York: Zed, 2010, ix. 
environmental policy is a radical change in heart and spirit. Havel writes: 'Only humankind understanding of its place in the universe will allow the development of new models of behaviour, scales of values, and objectives in life and, through these means, to finally bind a new spirit and meaning to specific regulations, treaties, and institutions.'

Finally, ethics, religion and spirit must engage the challenges of sustainable development and provide transformational leadership. David Orr and D. Paul Schafer in recent books ${ }^{52}$ identify these areas of transformational leadership, which may be taken as guides:

1. Creating a new theoretical, practical, historical, and philosophical framework for the world of the future;

2. Dealing with the intimate relationship that exists between people and the natural environment;

3. Fostering a vision of an humane and decent future;

4. Offering clarity about our best economic and energy options; and

5. Helping people understand and face what will be increasingly difficult circumstances.

\section{Particular Ethics and Spirituality Initative for Sustainable Development}

A particular Ethics and Spirituality Initiative for Sustainable Development ("ESI") began in December 2010 at the Earth Charter +10 Conference in Ahmedabad, India. The conference's working group on religion and spirituality framed action steps that included the development of a statement by religious and spiritual leaders aimed at Rio+20, which became "Towards Rio+20 and Beyond - A Turning Point in Earth History," a statement signed by many or Renaissance (Ottawa, Quebec: University of Ottawa Press, 2008). 
prominent religious leaders. ${ }^{53}$ In addition, in 2012, ESI developed a People's Sustainability Treaty on Ethical and Spiritual Values for Sustainable Development ("ESI Treaty"). ${ }^{54}$ This was one of fourteen such treaties that were proposed as alternative outcomes of Rio+20, given what was expected to be, and came to be, a weak set of commitments in the intergovernmental process at Rio+20. Over 70 groups were involved in ESI prior to and at Rio+20.

Leadership for ESI has come from, among other groups, Earth Charter International, the Center for Ecozoic Societies, Center for Environmental Education India, Jacob Soetendorp Institute for Human Values, Bahai' International Community, Interfaith Consortium on Ecological Civilization, Soka Gakkai International, Sukyo Mahikari, Brahma Kumaris, and Forum on Religion and Ecology at Yale. In efforts to influence the intergovernmental negotiations related to the United Nations, ESI has been associated with those involved in the Nongovernmental Organizations Major Group ${ }^{55}$ and has worked with the Stakeholder Forum. ${ }^{56}$ In addition,

53 "Towards Rio+20 and Beyond - A Turning Point in Earth History," an interreligious statement to the Rio +20 Conference, drafted in a 10-month international consultation led by the Jacob Soetendorp Institute for Human Values, www.soetendorpinstitute.org/images /stories /pdf/towards_rio_20_ and_beyond__carrying_document.pdf (accessed November 16, 2012).

54 "People's Sustainability Treaty on Ethical and Spiritual Values for Sustainable Development," http://sustainabilitytreaties.org/drafttreaties/ethical-and-spiritual-values/ (accessed November 16, 2012).

55 The 1992 Earth Summit in Rio recognized that nongovernmental actors would be critical to achieving sustainable development. Agenda 21 identified nine "Major Groups" that would have formal rights to participate in the UN sustainable development negotiations: business and industry, children and youth, farmers, indigenous people, local authorities, NGOs, scientific and technological community, women, and workers and trade unions. Religious and spiritual groups were not named as a separate Major Group and such groups have participated through association with one of the nine named groups. See the Major Groups tab of the Rio+20 website, 
ESI has been in consultation with the Great Transition Initiative and The Widening Circle, which seek to build a "Global Citizens Movement" to bring the transition about. ${ }^{57}$ Further, ESI has worked with each of the thirteen other People's Sustainability Treaties ("PSTs") and the coordinating group for the People's Sustainability Treaties. ${ }^{58}$

Rio+20 ended a phase of the work of ESI, but the outcome of Rio +20 and consultations held at Rio+20 made evident the need for ESI to continue in order to engage in the Post-2015 negotiations and, also, to continue work as coalition members for the transformative change needed for sustainable development. Richard M Clugston of Earth Charter International has continued to act as Coordinator of ESI and the author has worked closely with him over the last year.

http:/ / www.uncsd2012.org / majorgroups.html (accessed November 16, 2012).

56 "Stakeholder Forum seeks to provide a bridge between those who have a stake in sustainable development, and the international forums where decisions are made in their name." About-Stakeholder Forum for a Sustainable Future, http://www.stakeholderforum.org /sf/index.php/about-us (accessed November 16, 2012).

The Tellus Institute for a Great Transition, http://tellus.org/, The Great Transition Initiative, http://gtinitiative.org/, and The Widening Circle, http://www.wideningcircle.org/, are related. The Widening Circle describes the Global Citizens Movement as follows: "The global transformation will require the awakening of a new social actor: a vast movement of global citizens expressing a supranational identity and building new institutions for a planetary age. Such a global citizens' movement would work on all fronts, comprehending the various struggles for the environment and justice as different expressions of a common project." http://www.wideningcircle.org/ keyIdeas/GCM.htm. (accessed November 16, 2012),

58 For a list of the Peoples' Sustainability Treaties, see http:// sustainabilitytreaties.org/draft-treaties/. Each treaty has a circle of groups and individuals associated with it. 
The goal of ESI is to bring ethical and spiritual values into the sustainable development process for the purpose of bringing about transformative change and new narratives needed for the transition to sustainable development. The strategy is to create a coalition of religious, spiritual, and secular values-based organizations ("VBOs") to engage in this work. As ESI moves forward, it will exist as a core group that carries out certain activities for VBOs to support them in acting effectively to bring about sustainable development at personal, communal, and policy levels, and it will exist as a coalition of VBOs at policy levels and in providing mutual support and assistance. ESI will also exist as a part of a larger coalition, including groups to which ESI has been connected, for influencing UN Post-2015, and for building a global citizens' movement to bring about the political will for change.

ESI will operate out of certain core commitments:

- Three keys to sustainable development: poverty eradication, equity, and environmental conservation;

- Strong sustainability as expressed in the Earth Charter;

- Culture as the "fourth pillar" of sustainable development;,59

59 Sustainable development will not occur without cultural development. While, in principle, culture may be represented by the social pillar, the social pillar generally concerns human well-being, equity, justice and poverty alleviation in their ordinary usages. See Note 16 above. It does not stand for the changes in culture necessary to support sustainable development. Without culture as the fourth pillar, there is an implication that the values of modernity (or the Western model of development) are sufficient to bring about sustainable development. The implication is that people need to do things better, not to operate with new consciousness and sensitivities. The second purpose served by making culture the fourth pillar is to uphold the importance of cultural diversity, cultural heritage and wisdom, tolerance, and multiple paths of development. For further discussion, see, e.g., Jon Hawkes, The Fourth Pillar of Sustainability: Culture's Essential Role in Public Planning, Melbourne, Australia: Common 
- Need for transformative change and new narratives;

- Transformation at personal, communal and policy levels; and

- Importance of ethics, spirit and value to, and engagement of VBOs in, sustainable development;

The plan for the development of ESI will ultimately be decided by the coalition members. In the meantime, the following provisional five-point plan summarizes the principal activities that are proposed for ESI:

1. Develop ESI as a coalition of VBOs that will focus on bringing ethical and spiritual values into the sustainable development process;

2. Create and teach an educational program about VBOs and their role in sustainable development in the context of the Great Transition, the UN sustainable-development process, the Earth Charter, and the creation of a global citizens' movement;

3. Enable programs of action by VBOs at the personal, communal, and policy levels based on transformational leadership, new narratives and sustainable development as a moral imperative;

4. Facilitate effective policy action by VBOs in shaping the sustainable development goals for the UN post-2015 development agenda, and on the ongoing UN sustainabledevelopment process and related efforts at regional, national, and local levels; and

5. Bring into being an International Ethics Panel for Ecological Civilization ("IEPEC").

Ground, 2001, http://community culturaldevelopment.net.au// Downloads/awkesJon(2001)TheFourthPillarOfSustainability.pdf (accessed November 17, 2012); and Keith Nurse, "Culture as the Fourth Pillar of Sustainable Development" (June 2006), http:/ / www.fao.org/sard/common/ecg/2785/en/

Cultureas4thPillarSD.pdf (accessed November 17, 2012). 
Each of these is self-explanatory except for IEPEC. IEPEC was first proposed by Professor Ryoichi Yamamoto of Japan in September 2011 at the $8^{\text {th }}$ International Whitehead Conference in Tokyo. He argued that while intergovernmental panels existed to address the scientific aspects of sustainable development, there was not a panel to address the humanistic aspects. IEPEC would monitor progress toward sustainable development at various levels and would comment on ethical and spiritual issues in sustainable development. ${ }^{60}$

\section{Conclusion}

Sustainable development is a comprehensive term covering economic, social and cultural development, and environmental conservation. While the term is vague, it brings everyone to the table. It is in the global lexicon and whatever the differences in usages, it uniformly stands for an alternative mode of development that is sustainable within the limits of nature and addresses poverty and inequity. Without dramatic changes in the development path within the next forty years, there will be environmental and social catastrophe. Sustainable development is a moral imperative. Science, economics, and self-interest have not been sufficient to bring about the needed changes. Ethics, religion, spirituality and value within an historical context and with an understanding of the sustainable development processes need to be brought into the mix. There are many ways this can happen. One way is through an alliance of religious, spiritual and secular valuesorganizations in a particular Ethics and Spirituality Initiative for Sustainable Development. ESI was active in the preparation for Rio+20 and at Rio+20. It will continue to be active in the process of shaping the United Nations post-2015 development agenda and in other ways. ESI will be given form by and act through its coalition members.

60 The abstract of Professor Yamamoto's presentation is available at www.iwc8-japan.com/abstracts-papers/YamamotoRyoichi.doc (accessed November 16, 2012). 